\author{
イチョウの伝来は何時か…古典資料からの考察… \\ 堀 輝三 \\ 筑波大学生物科学系（テ305-8574 茨城県つくば市天王台 1-1-1）
}

\title{
A historical survey of Ginkgo biloba based on Japanese and Chinese classical literatures
}

Terumitsu Hori

Institute of Biological Sciences, University of Tsukuba, Tsukuba, Ibaraki, 305-8574 Japan

要旨：中国からわが国へのイチョウ伝来の論議では、その時期については、これまで飛鳥時代（7 世紀）から室町時代（16 世紀）までの 900 年にもわたる時間スケールにまたがり、かつその具体 的根拠や出典が示されない場合が多かった。一方、もたらされたものが、木、種子いずれであった かも曖昧のままにされてきた。本稿では、中国および日本に残る文献資料を中心に、最近韓国で発 見された遺物資料、ならびに筆者の観察を加えて、この二つの問題点について考察した。

イチョウが中国の町に登場したのは 10-11 世紀であり、11 世紀には市街地でも植栽され始め、 12 世紀には薬用効果が確かめられた。

現在知られる、イチョウに関連するわが国の最も古い文字資料は、1370 年頃成立の『異制庭 訓往来』である。しかし、最近 1323 年頃（元代前期）中国から博多へ向かう途中、韓国沿岸で沈 没した船から引き上げられた遺物の中からギンナンが発見された。これは、ギンナンが輸入果実と してわが国に持ち込まれた可能性を強く示唆している。輸入が始まった時期を示す資料は発見され ていないが、宋代末期の日宋交易にまで遡る可能性はある。輸入されたギンナンは室町時代中期 （1500 年代）までには国内に広まり、その中から木に育つものが出てきたと考えられる。したが って、伝来の時期は 13 世紀から 14 世紀にかけての 100-150 年くらいの間であろうと推定される。 今後、さらなる資料の発掘によって、より限定した時期の特定が可能になると期待できる。

Summary: My survey on a history of Ginkgo both in Japan and China was based on the Japanese and Chinese classical literatures. In China the literatures show that ginkgo started to be cultured in the urban areas in the early $10^{\text {th }}$ century and the herbal effects came to be known in the $12^{\text {th }}$ century. This plant was first recorded in a Chinese herbal called Shoko-honzo, edited in 1159. In Japan the oldest literature which records 'ginkgo' in Chinese character is Isei-teikin-ourai edited in about 1370. A report written in 1988 says that a sunken ship discovered in the sea near Korea is considered to have been sailing from China for Hakata in Kyusyu, Japan, about 1323. A ginkgo nut was among the relics pulled up from the ship. All the literatures and the discovery of the ginkgo nut in the sunken ship strongly suggests two important points; firstly ginkgo was introduced to Japan by the form of seed and secondly, the seeds were transferred at the period between the late $13^{\text {th }}$ and the early $14^{\text {th }}$ centuries.

Key Words: E.Kaempher, Ginkgo biloba, ginkgo, herbal, history, icho. 


\section{1.はじめに}

本学会誌の標徵マークでもあるイチョウ Ginkgo biloba L.（漢字では、銀杏、鴨脚（樹）、公孫 樹、白果等とも書く）の学名および和名に関し、その由来と当否を巡り 100 年以上にもわたって、 多くの意見が出されてきたことは衆知のことである。例えば、属名 Ginkgo の緅りについて、最近 では柴田（1997)は詳しい比較分析から、Ginkgoの gは $j$ であったであろうと結論している。

古く明治 38 年 (1905) の『植物学雑誌』

には、「Ginkgoナル緅ニ就テ」（筆者不明）

と題した記事が載っていて（図 1)、「 ......

同氏（ケンペル Engelbert Kaempfer のこと

）が日本二来遊シ此植物 見テ其名习問ヒシ

二當時答ヘシモノ愚カニモ銀杏ノ漢音ヨ以テ

セルヨケンペル氏ハ Ginkyo ト手記シ之ヨ印

刷スルニ當リ $y \ni g$ 卜誤マリ終ニ今日見ル 如キ……上憶測している。同誌の次号 225

号には、すぐに別の意見「Ginkgo二就テ」

（猺條子）が発表されている。筆者は、誤植 によってgになったもので、ケンペルの棳り 法ではjoであったはずだと、これまた憶測し ている。わが国におけるこの問題の論議は、 この頃から始まったと考えられる。同類の解 釈は近年でも受け継がれ、某社の生物学辞典 には、「ケンペルは Ginkjo と書いていた」と

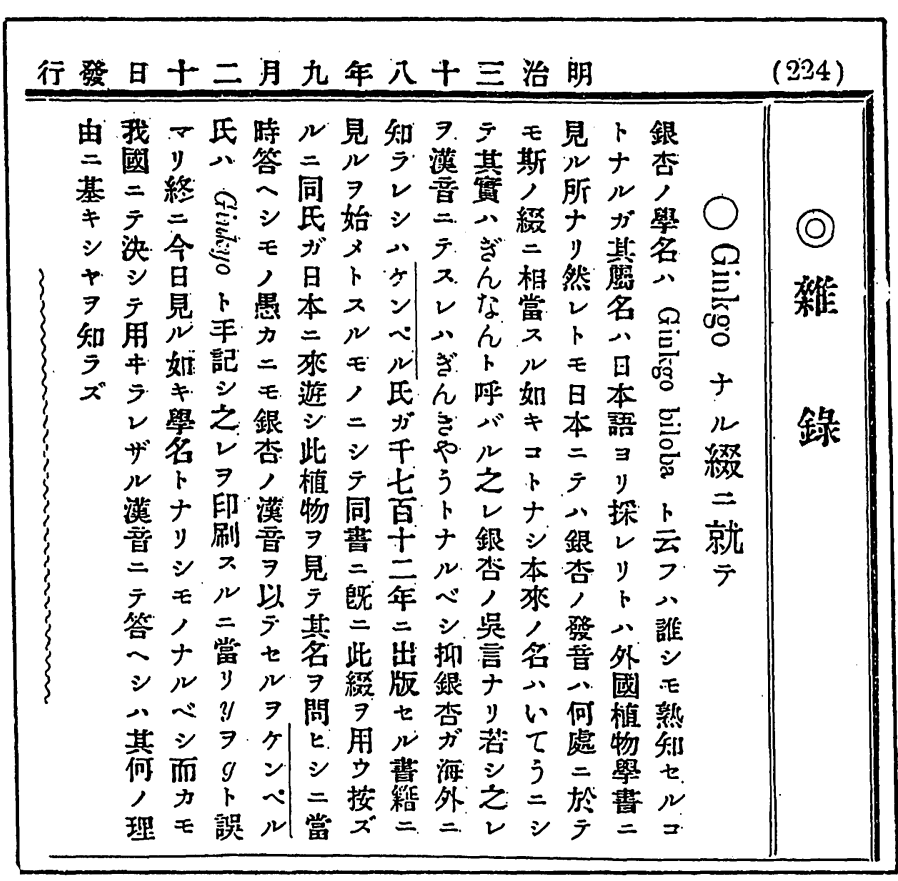

図 1 . 明治 38 年の『植物学雑誌』に載った属名 Ginkgoの綴りに関する、おそらく日本で最初の意見。 ある。しかし、ケンペル直筆の記録ノートや出版された『Amoenitatum Exoticarum』(以後、『アモ エニタータム』と略す）およびその素稿のいずれにも、明瞭に「Ginkgo」と書いてあることを指摘 しておきたい。誤植とか写し間違いとかというようなことは決して介在していないのである。

\section{2.イチョウの伝来時期}

イチョウが中国から.日本へいつ伝来したかという時期に関しても諸説がある。イチョウは日本人 には最も馴染みの媣い樹木の一つなので、樹木専門書、啓蒙書、辞典・辞書をはじめとして、いろ いろな分野の書物に風説的な伝来の記述がみられる。そのいくつかを挙げれば、「遣唐使が持ち帰 った」、「平安末期に中国より伝来」、「中国から朝鮮を経て輸入された」、「鎌倉時代に禅僧が宋から 銀杏を携えて来て、植えた小、「シナ原産で鎌倉時代に渡来」、「観音像の渡来と共に僧侶によって日 本に持ち込まれた」などである。これを時代的にみれば、飛鳥時代から、奈良、平安、鎌倉を経て、 室町時代までで、900 年という長い時間幅に含まれることになる。また、ほとんどの書物は、根拠 となる資料や出典を示していない。

「銀杏」という呼び名で注意しなければならないことは、現代語で「イチョウ」と発音したとき は樹木を指すが、「ギンナン」と発音したときは 核果を指すことである。漢字で「銀杏」と書か れている場合、振り仮名がなければ、樹木と果実のどちらを指すのか分からないことがしばしばで ある。文献の調査においても、このことに常に注意を払う必要がある。以下、日本と中国の古典資 
料をもとに、日本へのイチョウの伝来時期の上限年代の推定を行った。まず、1600 年代末から 1700 年代にかけて、植物科学にイチョウが登場する過程に簡単にふれ、以下わが国のイチョウの歴史に ついて時代を遡る形で述べることとする。

3. わが国の古典資料からの考察

$3-1$. 1600、1700年代

1637 年には、中国の本草書である『本草綱目』（李時珍著、1578 年（明代）頃）(以下『網目』 と略す）が日本で翻刻された。日本人は、この本から多くのことを学んだはずである。

「銀杏」は『綱目』の「果部」の項に入れられ、「…枇杷, 楊梅、桜桃、山桜桃」の説明の後に、

「銀杏」があり、その後には「胡桃、榛子…」が続く。

「銀杏」を「ギンキョウ」と音読みすることは可能だが、現代ではそうは読まない。しかし、学 名の Ginkgoの発音に近い、「ギンキャウ」（現代仮名遣いでは、「ギンキョウ」）というふり仮名を つけた本が 1600 年代に出されている。1617-19 年本『下学集』(筑波大学図書館蔵) である。『下 学集』については、後で詳しく述べるが、初版は 1444 年である。

1690-92 年に東インド会社の医師とし て来日したケンペルは、長崎滞在中の 2 年 間に 2 度、江戸まで参勤交代に随伴して往 来している。長崎およびこの道中で採集し た植物、約 300 種の記述と図を『アモエ ニタータム』の第 5 部「Flora Japonica」 に発表した（1712）。彼の精緻な細密画が ついた植物は 28 種で、その 1 つに「銀杏」 が含まれる（図 2)。この本によって、欧 州の人々は初めてイチョウという珍奇な植 物が東洋に存在することを知った。リンネ (Car von Linne ) は、ケンペルの『アモエ ニタータム』に書かれた記述と図を参考に して、イチョウの学名を Ginkgo biloba とした (1771)。

『アモエニタータム』執筆のための彼の 記録ノートや文献、および彼が日本から持 ち帰った植物標本は、現在、The British Library と The Natural History Museum

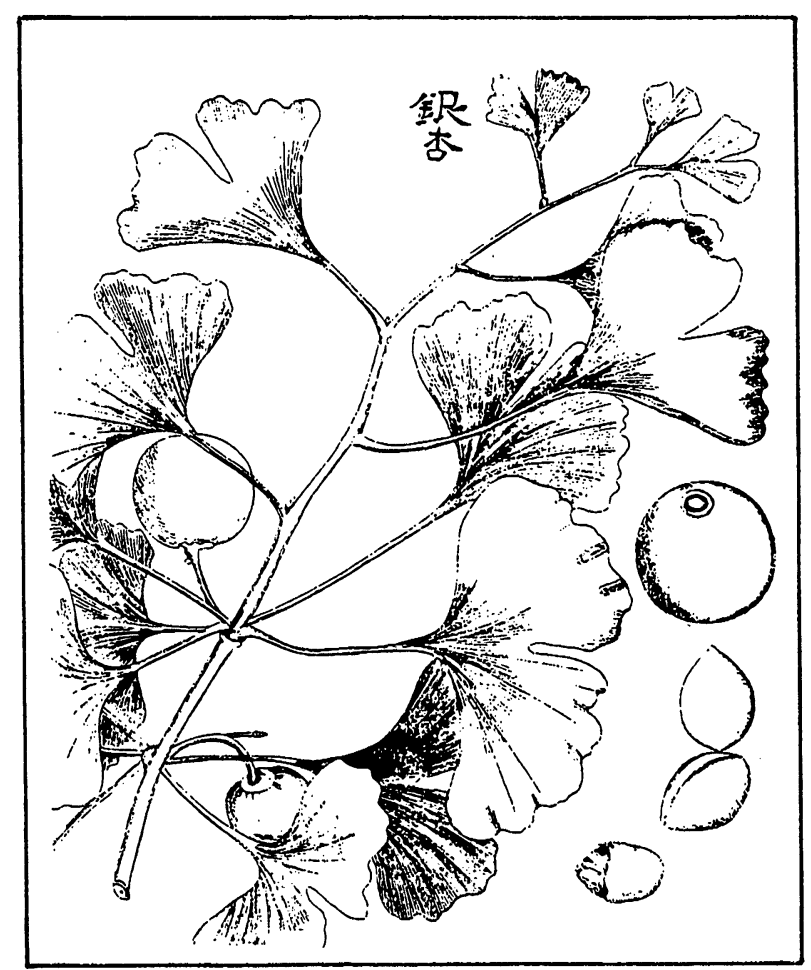

図 2. ケンペルノ描いた Ginkgo biloba の図

に保存されている。前者についてはその一部を、後者については全部を直接実見調査した。ケンペ ルの持ち帰った資料の中で、『アモエニタータム』の著作に最も関係したのが、江戸初期の百科図 鑑ともいうべき『訓蒙図菓（きんもうずい）』（以下『訓蒙』と略す）(中村惕斎、1666）である。The British Library にある彼の直筆の記録ノートには、「Kinmodusjui」（私注：きんもうずい）と夕 イトルをローマ字で書かれた表があり、『訓蒙』のローマ字書きの植物名とページ番号を書いた索 引があった。また別に、日本人が書いたと見える毛筆書きの「銀杏」が 2 力所あり、その一方の「銀 杏」の右側には、「イチヤウ」「ギナン」「ぎんあん」「ギンアン」「さんきやう」「サンキヤウ」の 6 
通りの片仮名、平仮名が、そしてローマ字で Gin an, Ginnan と書かれている。さらに、印刷され た『アモエニタータム』の「ウルシ」と「フウラン」の図の中に、「Kinmodusjui」というスペル が書き込まれており、その脇のメモから、彼は『訓蒙』を日本の植物図鑑として認識し、参照した ことがわかる。

わが国にある何冊かの『訓蒙』を調べてみると（図と説明の配置がケンペルの持ち帰ったものと は異なってはいるが)、植物名の多くには音読みがつき、その後に訓読みがついている。例えば、

「松」には、「志よう」「まつ」、「竹」には、「ちく」「たけ」となっている。ケンペルの持ち帰った 『訓蒙』の「イチョウ」の項を見ると、図の右上に漢字で縦書きに「銀杏」と書かれ、「さんきや う」と読めるふり仮名がついている。また、上欄の説明には「俗云ぎんあん杏従唐音一名白果銀杏 樹一名鴨脚樹いちやう」とあり、「はくくわ」「ぎんきやくじゆ」「あうきやくじゆ」と漢字にふり 仮名がついている。『アモエニタータム』を見ると、『松・Sjo,・Maats』(筆者注:ショウ・マッ)、

『竹・Tsiku・Tacke』(筆者注:チク・タケ) である。『アモエニタータム』の書き順が『訓蒙』 に倣ったことは明らかである。『アモエニタータム』のイチョウの記述は、『杏銀・Ginkgo・ Gin an〔筆者注:ギンアン〕・Itsjo〔筆者注:イチョウ〕』となっている。ケンペルは、明らかに『杏 銀』（当時の、右から左に書く綴り法に倣っている）の音読み「ギンキヤウ」を、彼の緅り法で Ginkgo と表記したのである。Ginkgoの「綴りと発音」についての見解は、すでに発表しているので（Hori \& Hori, 1997)、ここでは繰り返さない。

このように、「イチョウ」が Ginkgo という学名となった背景としては、18 世紀以後も版を重ね た『下学集』のうち、1617-19 年本、すなわち 17 世紀に翻刻された版にのみ、「銀杏」の読みと して「ギンキヤウ」という音読みが付されていること、そして、同様に音読みを採用している『訓 蒙』が 1666 年に出版され、ケンペルがそれを参照していることと強い関わりがあると考えられる。

\section{3-2. 1500 年代}

1523 年に著わされた『喫茶養生記・御飾書（おかざりのしょ）』(相阿弥著) は八代将軍足利義 政の持ち物の記録で、その中にイチョウの葉をモチーフとした「銀杏口の花瓶」が描かれている。 中国においては、下で述べるように本草的効用からイチョウの実が重用されたが、わが国では本草 書からの知識としてそれを知っていたであろうが、それにもましてイチョウ葉の美しい色あい、形 が人々を惹きつけ、このような芸術的デザインとして使われたものと考えられる。茶会の記録『松 屋会記』の「久政茶会記」（1533-96）では、1556 年と 1559 年の条に、菓子として「キンナン」 （仮名で記し、その横に銀杏とある）を出したことが書き残されている。1500 年代のわが国では、 イチョウの果、樹ともに人々の日常生活に樑く入り込んで行った様子がわかる。

\section{3-3. 1400 年代}

1400 年代では、 4 冊の文書に注目したい。大伴広公の『温故知新書』(1484 年成立)、一条兼良 (1422-81 年) が著した。尺素往来』(1481 年頃成立)、1450 年頃成立といわれる『長倉追罰記』 (戦場の記録)、1445-46 年頃の成立といわれる『壒囊鈔（あいのうしょう）』(行誉）である。『温故 知新書』と『尺素往来』には、ともに絵はないが「銀杏」があり、前者では「キアン」、後者では 「イチヤウ」というふり仮名がついている。『長倉追罰記』には、各隊のまん幕に描かれた家紋を 列記する箇所があり、その一つに「大石の源左衛門はいてうの木」とある。問答形式の辞書である

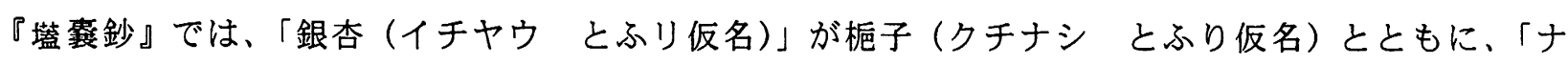


ニトハ」（=何であろう）と問い、答えとして「和名にも見えず」とある。この「和名」は、漢語 の注釈を主とした辞書『倭名類聚鈔』（930 年代、源順）である可能性も考えられるが、わが国の 最初の本草書『本草和名』( 914 , 深根輔仁) を指すと考えるのが妥当であろう。この記述は、植 物の項でなされているので、行誉は知識としてイチョウの漢名『銀杏』は知っていたが、イチョウ は見たことがないことを示している。

ところが、前年の 1444 年に刊行された字書『下学集』には「銀杏（イチヤウ のふり仮名）」が 載っており、さらに異名として「鴨脚」もある。また、名前の由来等も簡単に説明されている。こ の字書では「…胡桃・銀杏・木犀（モクサイ）…と続くことから考えて、イチョウは樹木として の位置づけになっていると思われる。初刊本は現存しないとされているが、筆者は室町時代から江 戸中期までに復刻された本を調査することができた。刊行年代の異なる 9 種類の本（そのうち 5 種 類は、牧野富太郎の蔵書、牧野文庫) を比較したところ、以下のことがわかった；(1)ずての本に 共通していることは、「銀杏」の右側に「イチヤウ」の振り仮名がつけられている。(2)「銀杏」の 左側には、別の読み方の振り仮名がつくものと、つかないものとがある。(3)左側に振り仮名がつか ないものは 5 冊あり、そのうちの 4 冊が 1400 年代〜 1500 年代に刊行されている。これらの

「銀杏」の読みは「イチョウ」だけである。(4)左側にもふり仮名がついているものは 4 冊で、その 全てが 1600 年代の刊行で、内訳は、「キンアン」、「キンキヤウ」、そして、「ギンキヤウ」であ る。前述したように、「ギンキヤウ」のふり仮名がついた本は、1617-19 年本の『下学集』だけで ある。室町中期にはイチョウの木はかなり一般化していたことを示している。

\section{3-4. 1300 年代}

現在の知見では、「銀杏」が文字として印刷された最も古い文書は、1356-75 年頃成立の『異制 庭訓往来』（虎関師練；「国史大辞典、吉川弘文館では撰者不詳とある」）である（西岡、1998）。初 刊本（現存するかどうか不明）を見ることはできないので、1683 年本（京都、小河多右衛門刊行 ; 筑波大学図書館蔵）を見ると、「銀杏」に「井テウ」のふり仮名がついている。しかし、『群書類従』 巻第百四十・消息部三（続群書類従完成会編）では「…金柑柑小温州（ウシュ と振り仮名）橘枇 杷林榙楊梅柘榴桃杏梅李梨鉛桃（クルミとふり仮名）銀杏柏實椎榛栗烏芋生栗干栗…」とあり、

「銀杏」にふり仮名はない。これら羅列された名前から考えられることは、銀杏も果実の一つとし て扱われていること、さらに、その多くは（高価な?）輸入品の果実であったように見受けられる ことである。イチョウは果実として伝来したことを示唆しているように思われる。しかし、この資 料とて、伝来年代を短い時間スケール内に限定できる文献とはいえない。日本国内の有史後の遺跡 から、イチョウの遺物が発見されることが待たれる（この分野の専門家に尋ねたところ、現在まで 縄文・弥生時代を含め、中世までの遺跡から、イチョウもしくはギンナン遺物の出土記録はないと のことである)。

文字表記された資料の探索以外に、絵画、衣装資料などの調查も必要と感じていたとき、友人が 地方紙のコラム欄に、富山県氷見市の上日寺に伝わる絵にイチョウとおぼしき木が描かれていると の記事が載っていたと教えてくれた。早速同寺を訪問して見せてもらったところ、盢一枚大の大き な絵であった。精彺な写実画ではないが、枝先に着く葉の形、枝・葉の伸び方はイチョウの新萌芽 の枝を思わせる絵である。文化財指定がされていないためか詳細な調査評価がなく、制作年代は不 明である。筆者が撮影した写真を美術史研究者に調べてもらうと、筆法等から判断して鎌倉一室町 時代に描かれたとの鑑定を頂いた。しかし、時間尺度が長く、それ以上の有用な情報は得られてい 
ない。今後の詳細な調査が待たれる。

絵画資料、特に絵巻物の調査を開始した直後、日本、中国の医学史・本草史研究が専門の真柳教 授（茨城大学人文学部）から、『弘法大師行状絵詞』にイチョウの葉のついた樹が描かれていると の情報を教授された。早速、1374-86 年頃成立（真鍋，1982）といわれる、この絵巻（『続日本絵 巻大成』；中央公論社刊版を参照した）の「青龍受法」の段、すなわち唐に行った空海が長安の青 龍寺で（恵果和尚から）密教を伝授されるところを描いた場面を調べた。伽藍の脇にイチョウの葉 とみえるものをつけた樹が描かれている。しかし、樹形はイチョウではない。葉がイチョウとする なら、当時の絵師は何らかの資料をもとに、実視したことのないイチョウの木を空想で描いたこと になる。絵師が空想で絵を描くということは、例えば『鳥獣戯画』に、日本にはいない動物が描か れていることからもうなずける。推論できることは、まだ日本国内では生育したイチョウの木はな かった可能性が高いということである。

韓国の沿岸の沈没船からギンナンの遺物資料が見つかっているとの情報を、ギンナンのコピー写 真を 1 枚添えて真柳教授からいただいていた。しかし、もっと詳しく知るために、韓国の友人に 調べてもらおうと考えながら、絵巻物の調査を先ず終えたいと思って図書館での調査を続けていた。 アジア諸国の美術関係図書が配架されている前を通過していたとき、何気なく目の端に入った本が、

真柳氏が教えて下さった、「新安海底遺物」（1988）という報告書であった。予期せぬものが眼前 にあった。韓国の文化公報部 文化財管理局発行の非売品・奇贈図書であった。第 III 章、第 4 節 の植物類の項に、沈没船から引き上げられた植物遺物の品々が報告されており、その中に教えてい ただいたギンナンの写真があった（詳細は省くが、胡椒をはじめ他に何種類もの果実が引き上げら れた)。朝鮮語を解する娘の協力を得て報告書の内容を読むと、この沈没船からは至治参年（1323 年、元の年号）と記された木牌（荷札に相当するもの）とともに、博多にある寺社名を記したもの が引き上げられたことを知った。これは、この船は中国から博多に向かった貿易船であったらしい こと、また、ギンナンを含む植物果実（種子）が輸入されていた、ことを示す重要な証拠と考えら れる。

\section{3-5. 1200 年代}

1205 年に編まれた『新古今和歌集』、1284 年に刊行された『本草色葉抄』（惟宗具俊）には、鴨 脚、銀杏は見いだせない。

鎌倉の鶴岡八幡宮にあるイチョウは、1219 年三代将軍源実朝を暗殺した公暁がその後ろに隠れ ていたという話のために有名である。しかし、『愚管抄』（慈円、1220）には、公曉が実朝を殺傷 したことは記されているが、イチョウの描写はない。イチョウに隠れたことをたどっていくと、『鎌 倉物語』（1659 頃、中川喜雲、）に行き着き、作者の創作であろうとされる（上原、1970）。この 樹についての成長錐による年輪実測調査（樹木総合診断調査報告書、神奈川県教育庁、1990）は、 樹令 500 年前後という結果を示している。すなわち、1500 年頃までは、鶴岡八幡宮にイチョウが 存在しなかったのである。しかし、中川喜雲がこの物語を書いた約 150 年後の 1659 年頃には、作 者の想像を膨らませるのに充分な太さのイチョウが生えていたのであろう。ところで、何故このよ うな創作が全国的に受け入れられたのだろうか？ それは、明治時代に全国の主要鉄道の「鉄道唱 歌」がつくられ、「汽笛一声新橋を…」で始まる東海道線編の唱歌の 7 番目に、「八幡宮の石段に 立 てる 1 木の大鴨脚 別当公暁のかくれしと 歴史にあるは此陰よ」と歌われ、全国に広まり、歴史的 事実のように信じられたのが一因であろうと考えられる。 
1200 年代後期に描かれた（小松茂美、1984）とされる、『玄奨三蔵絵』(『続日本絵巻大成』中 央公論社刊を参照）にもイチョウの葉と見える絵が描かれている。玄牀がインドに修行に出たとき の過程を描いたこの絵巻の絵は、『弘法大師行状絵詞』の場合と同じように、絵師の想像力による 創作のようである。イチョウは松を想わせる樹形に描かれている。おそらく何らかの資料を示され ただけで描いたのであろう。

したがって、1200 年代の国内にイチョウ（樹木であれ、ギンナンであれ）が存在したことを示 す信頼性の高い証拠は、現在のところ未だ一つも見いだされていない。

3-6. 1100 年代およびそれ以前

これまで調查し得た限りという条件はつくが、700 年代から 1100 年代末までの種々の資料の中 に、明瞭にイチョウを指す文物は見つかっていない。『万葉集』(700 年代末)、『入唐求法巡礼行 記』(838-847、円仁)、『古今和歌集』(913 年)、『本草和名』(前出)、『倭名類聚鈔』(前出)、『枕 草子』(1001、清少納言)、『源氏物語』(1010 頃、紫式部) 等である。また、『源氏物語絵巻』、寝 覚物語絵巻』、『伴大納言絵詞』、『吉備大臣入唐絵詞』、『信貴山縁起』、『粉川寺縁起』、『鳥獣戯画』 等の絵巻資料にも、明瞭にイチョウと判定できるものが描かれている場面は認められない。ただ、 戦場の武者や庶民の着る衣装装束の柄に、部屋飾り、盢の緑取り、衣冠装束の装飾部品に、イチョ ウ葉またはそれを組み合わせたようにも見えるものが多くある。これらについては、今後の調查研 究を待たねばならない。

文字資料の探查において注意しなければならないことは、「イチョウ」を表記する漢字として、 日本には「銀杏」が最初にもたらされたということだ。14 世紀以降に出された辞書、字書などの イチョウの見出し語は、すべて「銀杏」であることがその証拠である。「鴨脚」は別名として、中 国の文献による知識が紹介されているのみである。このことは、「イチョウ」という植物が日本に 入って来たのは、中国において、その名が「鴨脚（子、樹）」から「銀杏」に変わった 11 世紀以 後であったためと云える。

\section{4. 中国の古典資料からの考察}

中国におけるイチョウの歴史を調べるには、本草書をひもとくのが常道であろうと考え、誰もが 先ず見る李時珍の『本草綱目』（以下『綱目』と略す）を手がかりに、そこに引用されている文献 を調べるかたちで調查に着手した。『綱目』が著された 1500 年代末より数百年も前から、中国で は「銀杏」は一般的な植物になっていたので、本稿での対象年代は 120 年代以前に絞ることとす る。すでに述べたように、イチョウが中国で一般化した後、わが国に伝来したと考えられるため、 中国の歴史については年代順に述べていく。そのため、年代として『綱目』に触れる必要はないの だが、本草書が重要な情報源であるために、『綱目』の特徵を簡単に述べておく必要があろうと考 えろ。

各本草書は、基本的にはそれまでの古い文献を総集しており、改訂、増補で新しい知見が追記さ れる形式をとるので、参照文献の追跡が比較的容易である。『綱目』は、各植物について、釈名（別 名、名称の由来等)、集解 (産地、形状・鑑別法等)、正誤、修治……などの項目にわけて記述する という定型記載様式をとる。初刊本に最も近いとされる『金陵小字本』（内閣文庫所蔵）の第三十 巻（後刻本では、第二十九巻）「果部」に、山桜桃と胡桃にはさまれて「銀杏」がある。書かれて いる内容は、雌雄の区別など博物学的な認識にも触れているが、主要な部分は「ギンナン」の効用 
/害についてである。白果、鴨脚子という別名が記されているが、これらはギンナンを指したもの である。また、「銀杏」として描かれているものは（図 3)、とてもイチョウには見えない。これは、 李時珍自身はイチョウの木を実際に見たことはなく、図は絵師に任せきりにした可能性があること を示唆している。

さて、定型的記載様式に則って、 もう少し詳しく『綱目』を見るこ とにする。まず、見出し語の「銀 杏」の下に、「日用」と書かれてい る。「日用」とは『日用本草』 （呉端、1329）を指し、これによ って、「銀杏」を本草として最初 に記述した書物は『日用本草』で あったと時珍は認識していたこと を示す。第一の項目である[釈名】 では、別名として「白果」をあげ、 そこにも「日用」とあるが、「鴨脚 子」については出典が記されてい ない。こ扎は、その名が本草書や 農業書からの引用ではないためで あろう。続いて、「(時珍曰) 原生 江南葉似鴨掌因名鴨脚宋初始入貢 改呼銀杏因其形似小杏而核色白也

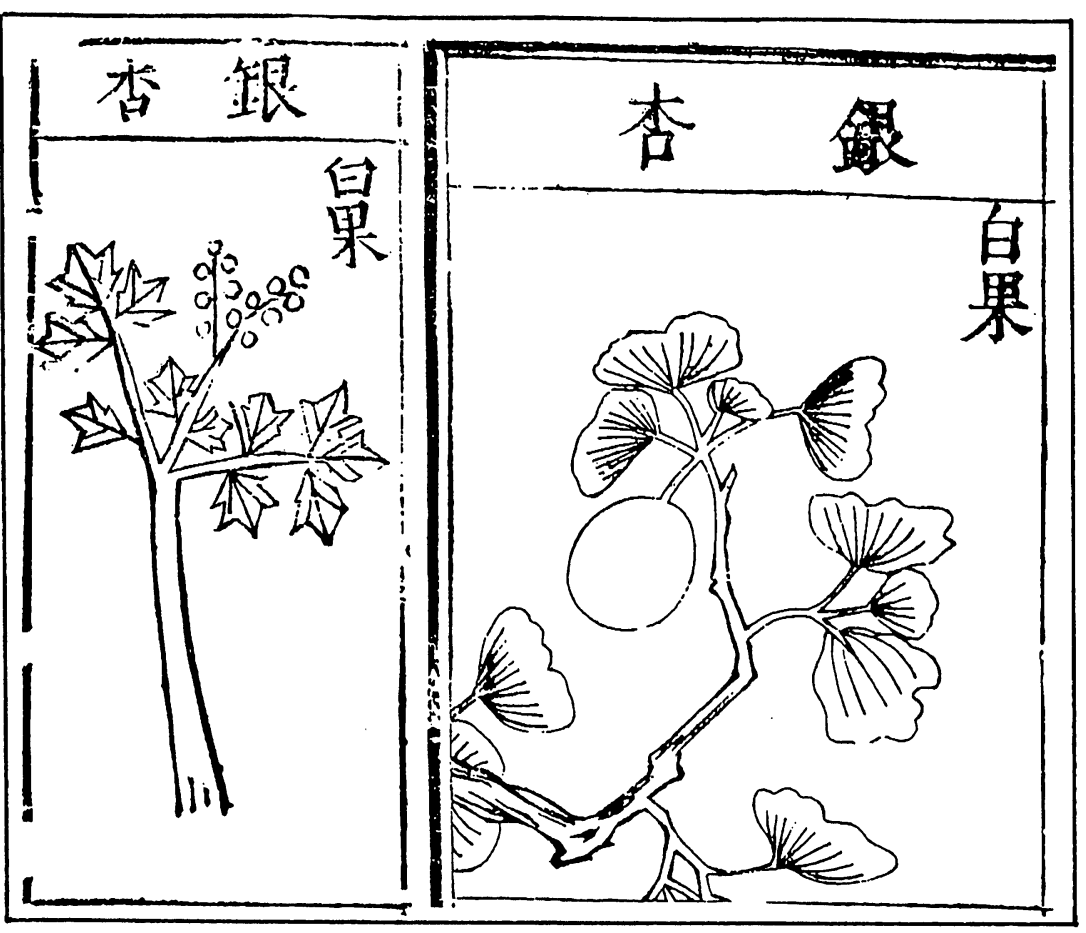

図 3.（左）『本草綱目』（金陵小字本）（内閣文庫所蔵）の 「銀杏」の図。（右）江戸時代、日本で翻刻された『大字 正誤 本草綱目』（牧野文庫蔵）の「銀杏」の図。 今名白果…」とあり、銀杏は「江

南（現在の安徽省宣城県のこと）に生えていた」、葉の形が「鴨の脚に似ていたので、鴨脚と名づ けなれていた」が、「宋代初期に貢ぎ物として献上する際、その実が銀色の杏に似ているため、呼 び名を銀杏と改めた」ことが記されている。第五項目〔発明〕は「(時珍曰) 銀杏宋初始著名而修 本草者不修不収…」（宋代の初めに銀杏が著名になったにもかかわらず、本草学者が本草書に収載 していない）という指摘ではじまり、銀杏の形態、効用などを時珍の見解として書いている。宋代 の本草書としては、『嘉祐本草』(1061)、『図径本草』(1062)、『重広本草図径』(1092)、『大観本 草』(1108)、『政和本草』(1116)、『本草衍義』（1119）などがあり、そのいずれにも「銀杏」が 収録されていないので、時珍はそれらのことを指したと思われる。

\section{4-1. 900 年代以前}

『神農本草経集注』(陶弘景；456-536)、『新修本草』（659、蘇敬）など、10 世紀までにいくつ かの本草書が著されているが、そのいずれにも「鴨脚」(「銀杏」は下で詳しく述べるように、11 世紀になるまで登場しない）の記録はない。

\section{4-2. 1000 年代}

『日用本草』(前出) 以前に、イチョウを記した文書が存在することは、第一項目の〔釈名〕に、 梅堯臣と欧陽修の二人の詩人の名前が記されていることから䇲われる。イチョウを扱った医方書や 
種々の古文書文献を集めた『古今図書集成』(陳夢雷編) には、『綱目』やそのたの文書、そして梅 堯臣の詩が 4 編、欧陽修の詩が 2 編収録されている。それらの詩から以下のことがわかる。

1 梅堯臣の故郷宣城では鴨脚が栽培されていた。

2 梅堯臣（1002-1060）と欧陽修（1007-1072）が生きた 11 世紀、イチョウの木は「鴨脚」、

実は「鴨脚子」と呼ばれていたが、入貢のため、実の形態から「銀杏」と改称した。

3 彼らの時代に、都（現在の開封市）にも植えられ、ギンナンが食されるようになった。

4 しばらくすると、ギンナンが一般にも広まり、高価なものではなくなった。

つまり、中国南部の一部でしか知られていなかったイチョウが、より広い世界へ広がり始めた のが 11 世紀前半で、それと同時に「鴨脚」、「鴨脚子」から「銀杏」に呼び名が変わり、文字とし ても印刻され始めた。

\section{4-3. 1100 年代}

すでに述べた通り、『政和本草』（前出）、『本草衍義』（前出）、大観本草』（前出）にはイチョウ は収録されていない。

イチョウの歴史にも関心を持って研究されている真柳氏（前出）から、時珍でさえ見ることので きなかった本草書が存在するとの教示を受けた。『昭興本草』（1159）である。この本は、日本に しか伝本が残らなかったとされている。「銀杏」という項を立て、その薬用を記した（外種皮を塗 ると、ほくろがとれる等)、現在知られる限り最古の中国の本草書である。別名として「鴨脚子」 をあげている。

4-4. 1200 年代

農業書の『全芳備祖』(1225 年頃) は、「銀杏」を「果部」で扱っており、ギンナンが重用され ていたことを示している。しかし、時珍の参照した文献の一覧には、上記の『昭興本草』とともに 『全芳備祖』は見られない。『延寿書』(1291) では「白果」が使われている。『綱目』の第五項目 〔発明〕ではこの書が引用されているにもかかわらず、時珍は何故か、「白果」の原著として時代 が下って書かれた『日用本草』を引用している。

\section{5. 総合考察}

イチョウが中国の人々の前に姿を現したのが 10-11 世紀、植栽され始めたのが 11 世紀、薬用 効果が本草家によって記載されたのが 12 世紀であることが確かめられた。

イチョウを木としてとらえるか、実としてとらえるかによって、イチョウの伝来のとらえ方が違 ってくる。木を直接わが国に持ち込んだことを示す文献は皆無である。しかし、直径が $5 \mathrm{c} \mathrm{m}$ 以上、 長さが $3-4 \mathrm{~m}$ もある枝ならば、適当な湿度が保たれれば、切り払われた枝でも翌春には花が開く ことを確かめた筆者の観察から推察すれば、当時の日中間の長い航海でも、生命力のある枝を持ち 込めた可能性は十分ある。しかし、それまでして、枝を持ち帰ったかどうかははなはだ疑問である。

わが国では、1300 年代にイチョウ（の実＝種子）の存在が知られ、記録されるようになった。 そして、室町時代中期（14 世紀）には急速に広まり、あちこちで木が生えるようになったと考え られる。

ギンナンは、今日でも生のまま保存され、食される。焼いて日数が経つと風味が無くなるので、 当時も食するまでは生のまま保存したと考えるのが妥当である。したがって、日本へ持ち込まれた 
ときも生きたギンナンであった可能性が大である。筆者の経験では、室内常温保存であれば翌年は $100 \%$ に近い発芽率で、経年につれて発芽率は減ずるが、3 年までは発芽するものがある。外国か ら持ち込まれたギンナンでも、幾ばくかの年月を経た後でも発芽し得る可能性を示しており、1 14 世紀のわが国で実際に起こっていたとしても不思議はない。韓国でみつかった沈没船（14 世紀前 半）からの引き上げ遺物のなかにギンナンが発見されたことは，その可能性を強く示している。現 在のところ上記のような物的証拠資料は発見されていないが、実の伝来時期が 1200 年代にまで遡 り得る可能性も否定できない。何故なら、宋代後期や元代初期（13 世紀後半）の交易船によって 持ち込まれたことも予想されるからである。

以上、現時点における、知られた資料にもとづく、わが国におけるイチョウの歴史を考察した。 こうした調査では、現状では 50-100 年を最短時間単位として考察せざる得ない。したがって、本 稿でも段階的結論として推測表現を取らざる得えない。しかし、今後、未発掘の地域資料が見つか れば、より厳密な考察が期待できる。科学的方法、例えば年輪測定が古木イチョウについてできれ ば、一気にこうした問題は解決できようが、それは不可能である。また、松や杉では生長錐による 年輪測定は有効でも、古木イチョウには無力である。イチョウは、松や杉とは違う肥大生育様式を とり、いわゆる「乳」が本体幹や枝から何本も垂下し、特に古木では本体に合体癒合することがし ばしば起こる。100年も過ぎれば、外見的には本体幹と区別がつかなくなってしまう。

謝辞：日本、中国の医学史・本草史の研究が専門で、自身もイチョウの研究をしている茨城大 学人文学部教授・真柳誠氏は、特に中国の古文献に関する多くの重要な知識と貴重な資料の提供を 快く下さった。また、西岡芳文氏（金沢文庫）からは、日本のイチョウに関する多くの資料の教授 を頂いた。記して、両氏に深謝の意を表す。The British Library の Dr. Yu-Ying Brown, The Natural History Museum の Dr. M. Roberts は資料閲覧の便宜を与えて下さった。記して感謝の 意を表す。また、牧野文庫に対し、蔵書の閲覧許可を下さったことに感謝の意を表す。最後に、妻 堀志保美は本稿について、多くの貴重な批判と意見を与えてくれた。記して、感謝の意を表す。

文献（古文献については、本文中に著者、編者名、発行年（代）、および必要に応じて所蔵場所を記したので省略する） Hori, S and Hori, T. (1997) A cultural history of Ginkgo biloba in Japan and the generic name Ginkgo. In : Hori, T. et al .(eds) Ginkgo Biloba- A Global Treasure. From Biology to Medicine. Springer-Verlag Tokyo, pp.385-411

小松茂美（1981）続日本絵巻大成 7 :玄牀三藏絵、中央公論社

真鍋俊照（1982）続日本絵巻大成 $5:$ 弘法大師行状絵詞 、中央公論社

西岡芳文（1998）歴史のなかのイチョウ、三田中世史研究 $5: 1-26$

柴田松太郎（1997）イチョウの属名 Ginkgoについての一考察、地球科学、51:371-376

上原敬二(1970) 樹木図説 第二巻イチョウ科、加島書店 